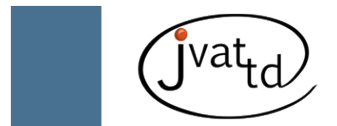

\title{
Ethical considerations of artificial insemination
}

\author{
Avila RE (1), Samar ME (2)
}

(1) School of Medical Sciences, National University of Córdoba, Córdoba, Argentina; (2) School of Dentistry, National University of Córdoba, Córdoba, Argentina.

\section{Dear Editor,}

After reading your previous editor's viewpoint, "Integrity in scientific publication", about ethical problems in scientific papers, I started to think one more time of another ethical issue in medicine: artificial insemination (1).

Artificial insemination (AI) is the most simple and oldest method in assisted reproductive technology, which has a low degree of complexity. Essentially, it involves placing sperm - previously prepared in the laboratory - in the female internal genital tract without sexual contact (2). AI carries the associated risk of multiple gestation pregnancies, since before the procedure women are given drugs that induce ovulation. This also leads to the possibility of a superovulation (ovarian hyperstimulation syndrome).

If the fertilization of several eggs really occurs, selective fetal reduction may be necessary, which comprises a paradoxical situation for women eager to have a child. Moreover, there must be an informed consent signed by women providing information on side effects of the technique, such as nausea, vomiting, ovarian enlargement and the possibility of occurrence of ovarian cysts (3).

The first question that arises from assisted reproduction is that it involves a type of human procreation dissociated from sexual partners. In addition, it is not therapeutic in its nature and do not cure infertility or reverse this situation (4).

Interestingly, the controversy or legitimacy of assisted reproduction techniques relies particularly on women. It may follow different positions according to the concept of family. Several people consider that the concept of family includes even those constituted by a single woman and her children. Consequently, this statement legitimizes the desire of single women for assisted reproduction methods. This situation creates a paradox since the right to reproduction is not an exercise of individual persons, but of a couple.

An argument against AI of single women is the welfare of the child, who has the right to fit into a comprehensive family relationship (with a mother and a father). Regarding the artificial insemination donor (AID), important questions arise. Should the identity of the donor who provided sperm for couples be revealed? What information will be given to the child in the future?

The legal and ethical questions are amplified in cases of post-mortem insemination, and sperm donor replacement without the consent of the spouse or steady partner. The son born after postmortem insemination is called posthumous child. Defenders of this technique agree that the sperm donor must leave a written approval for the use of his sperm after his death. However, others claim that the child loses his inheritance rights. Another dilemma arises in cases of divorce or separation of the couple before the death of the father.

The use of a donor in AI introduces new genetic material into a family, which is foreign to the couple. There is a great chance that, in a 
sperm bank, the same material will be used for multiple inseminations; therefore, those children will be half-brothers. Furthermore, there may be consequences of consanguineous marriages of half-brothers that are unaware of their own condition. Tests should be performed on semen to certify its quality according to the standards of the World Health Organization. Among the questions that artificial insemination raises are: What are the criteria for choosing a donor?, What is his relation with the unborn child?, Should the husband or partner give a formal consent that the woman will be inseminated with donor semen? (5).

It is a new type of family, a "pluriparental" one, comprised of biological mother, legal father, sperm donor (biological father) and child. The inseminated woman is the biological mother; consequently, her rights and duties in relation to motherhood remain unchanged. However, if the woman is in a stable relationship and did not ask her partner for his consent regarding AI, she committed a serious mistake.

\section{COPYRIGHT}

(C) CEVAP 2011

\section{SUBMISSION STATUS}

Received: October 29, 2011.

Accepted: November 3, 2011.

Full paper published online: November 30, 2011.

\section{CONFLICTS OF INTEREST}

There is no conflict.

\section{CORRESPONDENCE TO}

RODOLFO E. AVILA, Pabellón de Biología Celular, Ciudad Universitaria, 5000 Córdoba, Argentina. Phone: +54 351 4510182. Email: ravila@cmefcm.uncor.edu.

\section{REFERENCES}

1. Rode SM. Integrity in scientific publication. J Venom Anim Toxins incl Trop Dis. 2011;17(2):118.

2. Avila RE, Samar ME. La telemedicina y el embrión humano como paciente: implementación de nuevas metodologías en la enseñanza de la embriología humana. Informed J. 2004;III(IV).

3. Avila RE, Samar ME, Ferraris RV. El embrión como persona y paciente. Córdoba: Editorial SeisC; 2008.

4. Samar ME, Avila RE, Ferraris R. Etica en reproducción asistida en los albores del siglo XXI. Rev Med Córdoba. 2001;89:34-43.

5. Samar ME, Avila RE. Problemática jurídicolegal de la fertilización asistida. La persona y el comienzo de la vida. Claves Odontol. 2002;49:79. 